\title{
ENERGY DENSITY MODEL FOR FOREST SPECIES FROM CERRADO ${ }^{1}$
}

\author{
CARLOS JOSÉ DA SILVA ${ }^{2 *}$, AILTON TEIXEIRA DO VALE ${ }^{3}$
}

\begin{abstract}
Wood is the main source of energy in the energy matrix of underdeveloped countries, in addition to having a significant participation in developing countries, ranking fourth in Brazil. Thus, this study aimed to determine a model for determining the energy density of forest species from the Cerrado. Samples of trunks and branches were collected from 34 forest species in an area of 10.15 ha located in the Cerrado region aiming for immediate analysis, i.e. the contents of ashes (ASH), volatile matter (VM), fixed carbon (FC), and higher calorific value (HCV). Data from dry and saturated mass were obtained in order to determine the basic density. The species presented values of VM ranging from 77 to $85.5 \%$, ASH from 0 to $1 \%$, FC from 14 to $23 \%$, and HCV ranging from 18,282 to $20,121 \mathrm{GJ} \mathrm{ton}^{-1}$. A significant relationship was found between VM and FC $\left(R^{2}=0.9927\right)$ whereas no significant values were found between HCV and basic density. The average value of energy density considering the 34 species was $12,459 \mathrm{Mcal} \mathrm{m}^{-3}$. The estimated energy density of the area was $1,378,541 \mathrm{Mcal} \mathrm{ha}^{-1}$. The proposed model for calculating the energy density as a function of basic density favors energy surveys of areas to be explored since there is no need for calorific value analysis.
\end{abstract}

Keywords: Energy. Wood. Savannah.

\section{MODELO PARA DETERMINAÇÃO DE DENSIDADE ENERGÉTICA DE ESPÉCIES FLORESTAIS DO CERRADO}

RESUMO - A madeira é a principal fonte de energia na matriz energética dos países subdesenvolvidos e nos países em desenvolvimento a participação é significativa, ocupando o quarto lugar no Brasil. Sendo assim, o objetivo desse trabalho foi determinar um modelo para determinação da densidade energética de espécies arbóreas do Cerrado. As amostras foram coletadas de árvores em uma área de cerrado de 10,15 hectares. Foram coletadas amostras de tronco e galhos de 34 espécies florestais para análise imediata (cinzas, material volátil, carbono fixo) e poder calorífico superior. Dados de massa seca e massa saturada foram obtidos para a determinação da densidade básica. As espécies apresentaram valores de teor de material volátil entre $77 \% \mathrm{e}$ $85,5 \%$, teor de cinzas entre 0 e $1 \%$, teor de carbono fixo entre $14 \%$ e $23 \%$. O poder calorífico superior ficou entre $18.282 \mathrm{GJ} /$ ton e $20.121 \mathrm{GJ} /$ ton. Quando testadas as relações entre as variáveis da análise imediata (MV, $\mathrm{CZ}$ e CF), e o poder calorífico superior (PCS), foi encontrada relação significativa entre $\mathrm{MV}$ e $\mathrm{CF}\left(\mathrm{R}^{2}=\right.$ 0.9927), enquanto o poder calorífico superior e a densidade básica das espécies não apresentaram relação significativa. O valor médio da densidade energética para as 34 espécies foi de $12.459 \mathrm{Mcal}^{-3}$. A estimativa da densidade energética da área foi de 1.378.541 Mcal/ha. O modelo proposto para o cálculo de densidade energética em função da densidade básica facilita os levantamentos energéticos de áreas a serem exploradas, pois não há necessidade da análise de poder calorífico.

Palavras-chave: Energia. Madeira. Savana.

\footnotetext{
${ }^{*}$ Corresponding author

${ }^{1}$ Received for publication in $11 / 16 / 2016$; accepted in 06/27/2017.

Paper extracted from the doctoral dissertation of the first author.

${ }^{2}$ Departament of Plant Science, Universidade Federal Rural do Semi-Árido, Mossoró, RN, Brazil; carlos.silva@ufersa.edu.br.

${ }^{3}$ Departament of Forestry Engineering, Universidade de Brasília, Brasília, DF, Brazil; aiton.vale@gmail.com.
} 


\section{INTRODUCTION}

Brazil stands out in terms of energy resources since it has all the primary energy sources, with a favorable scenario for its energy demands in long-term (VENTURA FILHO, 2009). This is due to its large territorial area, almost all located in tropical and rainy regions, which offers excellent conditions for the production and energetic use of biomass in large-scale.

Most of the energy biomass in Brazil is used for the production of charcoal, which makes the country the world's largest producer and consumer of this product (BARCELLOS, 2007). In this context, Cerrado biome is one of the energy sources of Brazil due to its unique ecological aspect, as well as its peculiar physiognomies (SILVA; VALE; MIGUEL, 2015).

Wood (firewood and wood products) is the oldest source of fuel used to produce energy and it is an essential component in meeting Brazil's energy demand. This energy source will probably continue to be predominant, with most of the consumption located in the production sectors of charcoal, household, industrial, and agricultural (NASCIMENTO; BIAGGIONI, 2010; BRITO, 2007).

Although the large use of wood for energy purposes, few studies describe the performance characteristics of Brazilian species (CINTRA, 2009). Thus, the knowledge of some physical aspects of wood, such as its basic density, is essential for the assessment of its qualities for producing energy inputs, especially charcoal, since a high wood density implies more mass per unit volume and hence more energy (BARCELLOS, 2007).

In addition, the influence of immediate analysis (ashes, volatile matter, and fixed carbon), higher calorific value, and energy density are very important in order to determine the energy potential of wood (ANDRADE; CARVALHO 1998; QUIRINO et al., 2005). Thus, considering the importance of these variables in the use of wood for energy purposes, the aim of this study was to determine a model for the energy density of Cerrado species.

\section{MATERIAL AND METHODS}

\section{Study area}

Wood samples were collected from trees in a Cerrado area of 10.15 ha located in the Lajeado State Park, with a total area of 9 thousand hectares of Cerrado (COLEN; SILVA; MARTINS, 2007). The area is located in the central-west region of Tocantins State, Brazil, near the city Palmas.

\section{Methodological procedures}

Data from the area inventory were used, which presented 2473 individuals, totaling 80 species. From this total, 34 species were selected for sampling of trunks and branches and submitted to immediate analysis, i.e. ashes (ASH), volatile matter (VM), and fixed carbon (FC), and higher calorific value (HCV) (Table 1). Dry and wet mass data were registered for basic density analysis. The number of individuals of each species cut down was determined from the forest inventory, where approximately 3\% of trees with $\mathrm{DBH}>5 \mathrm{~cm}$, or at least one individual of each species, were collected with permission of the Environmental Agency of Tocantins State (NATURATINS). Disks of $5 \mathrm{~cm}$ thick were collected from each individual cut down in three positions of the trunk (base, middle, and top) and in three diameters of the branches (thick branch, with a diameter higher than $10 \mathrm{~cm}$; medium branch, with a diameter of 3 to $10 \mathrm{~cm}$; and thin branch, with a diameter lower than $3 \mathrm{~cm}$ ). This material was milled, graded below 60 mesh, stored in properly labeled containers, and oven dried at $103 \pm 2{ }^{\circ} \mathrm{C}$.

The analyses were carried out having as reference the following Brazilian standards:

- NBR 8112: Immediate analysis. Determination of the contents of moisture, ashes, volatile matter, and fixed carbon of charcoal;

- NBR 8633: Determination of calorific value. It prescribes the method of determining the higher calorific value of the wood at constant volume in an adiabatic, isothermal, or static calorimetric pump.

Energy density (De) was determined as shown in Equation 1:

$$
\mathrm{De}=\rho_{\mathrm{b}} \times \mathrm{HCV}
$$

Where $\rho_{b}$ is the basic density $\left(\mathrm{kg} \mathrm{m}^{-3}\right)$ and $\mathrm{HCV}$ is the higher calorific value (GJ ton ${ }^{-1}$ ).

\section{Data analysis}

Data were analyzed by means of analysis of variance (ANOVA). A simple linear regression was used to verify the relationship between variables. The choice of regression models was based on the coefficient of determination $\left(\mathrm{R}^{2}\right)$ at $5 \%$ probability level, standard error, residual analysis, and significance. The tests were performed by using the package Stats from R (R DEVELOPMENT CORE TEAM, 2015).

The equation best explaining the energy density estimation of trees as a function of basic density followed the traditional methods of linear regression in the sequence of importance according to Draper and Smith (1981). In other words, it was based on the graphical analysis of residuals (\%) and behavior of the adjusted model in relation to the real basic density, standard error of estimation (absolute 
and percentage, i.e. $\mathrm{S}_{\mathrm{yx}}\left(\mathrm{m}^{3}\right)$ and $\mathrm{S}_{\mathrm{yx}}(\%)$, respectively), adjusted coefficient of determination ( $\mathrm{R}^{2}$ adj.), and Fischer's F-value.

The proposed model considered was:

$$
\mathrm{DE}=\beta 0+\beta 1 \times \mathrm{D}_{\mathrm{BA}} \text {, }
$$

Where $\mathrm{DE}$ is the average energy density of the tree $\left(\mathrm{Mcal} \mathrm{m}^{-3}\right), \beta 0+\beta 1$ are the coefficients to be adjusted, and $\mathrm{D}_{\mathrm{BA}}$ is the average basic density of the tree $\left(\mathrm{kg} \mathrm{m}^{-3}\right)$.

The data of inventory carried out in the area were used for analyzing the energy density per hectare, totaling 80 species in a sample area of 2.16 ha (MIGUEL et al., 2016). Average values of tree density and the model adjusted for energy density were used.

\section{RESULTS AND DISCUSSION}

The Cerrado tree species assessed in this study presented values of VM between 77.4 and $85.5 \%$ (mean $=82.88 \%$ ), ASH between 0 and $1 \%$ (mean $=0.27 \%$ ), and FC between 14 and $23 \%$ $($ mean $=16.84 \%)($ Table 1$)$. The species presenting the highest values for VM were Byrsonima laxiflora Griseb (85.63\%), Conarus perrotetti $(85.62 \%)$, and Qualea parviflora $(85.95 \%)$ whereas the lowest values were registered for Ferdinandusa elliptica $(77.42 \%)$ and Tapirira guianensis (77.81\%). The highest value of ASH was recorded for Myrcia splendens $(0.83 \%)$, while the lowest value was found for Bowdichia virgiloides $(0.02 \%)$. FC ranged from $13.69 \%$ (Qualea parviflora) to $22.24 \%$ (Ferdinandusa elliptica).

According to Brito and Barrichelo (1978), the immediate analysis of a fuel gives the percentage of material burning in the gaseous (volatile matter) and solid (fixed carbon) states, as well as an indication of the residual material (ashes). Vale, Brasil and Leão (2002), Chaves et al. (2013), and Brito and Barrichelo (1982) recommended for biomass, in general, volatile matter contents between 75 and $85 \%$ and fixed carbon between 15 and $25 \%$. Cintra (2009) worked with native forest species in São Paulo State, Brazil and found values of volatile matter between 79.6 and $84.9 \%$. The values found in our study for these variables are in accordance with those found in the literature for wood and their variation is influenced by the species. The average ASH varied according to the species, but with values considered close to those of planted forests in Brazil, indicating acceptable results for energy purposes by the analyzed material. According to Chaves et al. (2013) and Pincelli (2011), woods with a high ash content are not recommended for energy purposes for being a substance that remains in the solid form and it does not combust. Vidaurre et al. (2012) studied the energy properties of Paricá wood (Schizolobium amazonicum) and found an average ash content of $1.3 \%$, which is considered high when compared to the ash content of Eucalypt. Morais, Nascimento and Melo (2005) found an average value of $1.26 \%$ for wood of Pinus oocarpa and related this high value to the higher content of inorganic compounds in the wood of this species when compared to others. Barcellos (2007) and Moutinho et al. (2016) found differences in ash content according to the studied species, with values ranging from 0.12 to $1.11 \%$. Vale, Brasil and Leão (2002) reported values between 0.15 and $2.73 \%$ for 47 Cerrado species, indicating that the values found in our research were similar to those found in the literature.

According to Chaves et al. (2013), during the burning of plant biomass volatile matter rapidly volatilize, which contributes to a low energy efficiency since fuel residence time decreases due to its rapid volatilization. A strong and inversely proportional relationship is usually found between volatile matter and fixed carbon. On the other hand, fixed carbon is directly related to the calorific value. A higher fixed carbon content in the material implies a longer fuel residence time.

Vale, Brasil and Leão (2002) found an average value of fixed carbon of $20.73 \%$ for Cerrado woods, Almeida et al. (2015) reported values between 17 and 18.57\%, and Cintra (2009) found values between 14.4 and $19.6 \%$, which is close to those found in our study. Chaves et al. (2013), Silva (2013), and Barcellos (2007) emphasized that fixed carbon content presents a negative relation with volatile matter content

The higher calorific value was between 18,282 GJ ton ${ }^{-1}$ for Parkia platycephala and 20,121 GJ ton $^{-1}$ for Pouteria ramiflora (mean $=19,233$ GJ ton $^{-1}$ ). Pinheiro, Rendeiro and Pinho (2005) found values for the higher calorific value of vegetal residue ranging from 18,810 to $20,900 \mathrm{GJ}$ ton $^{-1}$ regardless of particle size and density of biomass or origin wood in the case of sawdust. Brito (1993) points out that the variation in higher calorific value for wood, in general, is between 14,630 and 20,900 GJ ton ${ }^{-1}$. The average values cited in the literature are in agreement with those found in our study, i.e. between 18,282 and 20,121 GJ ton ${ }^{-1}$. Couto et al. (2004) observed an HCV value for wood of 18,366 GJ ton ${ }^{-1}$. Quirino et al. (2005), studying the higher calorific value of forest species, found values between 14,003 and 21,986 GJ ton ${ }^{-1}$, with an average value of 19,779 GJ ton $^{-1}$. In addition, Vidaurre et al. (2012) registered an average value of $18,638 \mathrm{GJ}$ ton $^{-1}$ whereas Vale, Brasil and Leão (2002) observed values ranging from 18,876 to 20,854 GJ ton $^{-1}$ considering 47 Cerrado species. 
Table 1. Immediate analysis of wood of 34 woody species from the Brazilian Cerrado, Tocantins State.

\begin{tabular}{|c|c|c|c|}
\hline Species & VM (\%) & ASH (\%) & $\overline{F C(\%)}$ \\
\hline Aspidosperma subincanum Mart. & 81.52 & 0.30 & 18.18 \\
\hline Byrsonima laxiflora Griseb. & 85.63 & 0.09 & 14.28 \\
\hline Byrsonima pachyphylla A. Juss & 83.17 & 0.10 & 16.73 \\
\hline Byrsonima sericea A.Juss. $B$ & 83.39 & 0.37 & 16.24 \\
\hline Bocageopsis multiflora (Mart.) & 81.07 & 0.07 & 18.86 \\
\hline Bowdichia virgiloides Kunth. & 85.58 & 0.02 & 14.40 \\
\hline Connarus perrottetti (DC.) Planch & 85.62 & 0.06 & 14.32 \\
\hline Connarus suberosus Planch & 83.98 & 0.43 & 15.59 \\
\hline Dalbergia densiflora Benth. & 85.34 & 0.28 & 14.38 \\
\hline Emmotum nitens (Benth.) Miers. & 85.11 & 0.27 & 14.62 \\
\hline Ferdinandusa elliptica Pohl. Pl. Bras. & 77.42 & 0.34 & 22.24 \\
\hline Erythroxylum daphnites Mart. & 84.71 & 0.20 & 15.09 \\
\hline Himatanthus sucuuba (Spruce ex Mull. Arg.) & 82.12 & 0.19 & 17.69 \\
\hline Inga alba (Sw.) Willd. & 85.35 & 0.56 & 14.09 \\
\hline Licania apetala (E. Meyer) Fritsch. & 82.29 & 0.33 & 17.38 \\
\hline Mabea fistulifera Mart. & 83.98 & 0.14 & 15.88 \\
\hline Maprounea guianensis Aubl. & 80.86 & 0.18 & 18.97 \\
\hline Matayba guianensis Aubl. & 84.30 & 0.32 & 15.13 \\
\hline Mezilaurus itauba (Meissn.) Taub. & 83.30 & 0.33 & 16.37 \\
\hline Miconia albicans (Swartz) & 82.24 & 0.54 & 17.22 \\
\hline Miconia cuspidata Mart. Ex Naudin. & 81.79 & 0.37 & 17.84 \\
\hline Myrcia splendens (Sw.) DC. & 81.00 & 0.83 & 18.17 \\
\hline Ouratea ovallis (Pohl) Engl. & 82.41 & 0.12 & 17.47 \\
\hline Parkia pendula (Willd.) Benth. & 84.44 & 0.04 & 15.52 \\
\hline Parkia platycephala Benth. & 82.57 & 0.45 & 16.98 \\
\hline Pouteria ramiflora (Mart.) Radlk. & 82.19 & 0.26 & 17.55 \\
\hline Protium heptaphyllum Mart. & 81.19 & 0.22 & 18.59 \\
\hline Qualea parviflora Mart. & 85.95 & 0.36 & 13.69 \\
\hline Sacoglottis guianensis Benth. & 83.73 & 0.17 & 16.10 \\
\hline Pouteria ramiflora (Mart.) Radlk. & 82.19 & 0.26 & 17.55 \\
\hline Tachigali vulgaris L. G. Silva \& H. C. Lima. & 82.68 & 0.31 & 17.00 \\
\hline Tapirira guianensis Aubl. & 77.81 & 0.40 & 21.79 \\
\hline Virola sebifera Aubl. & 79.70 & 0.10 & 20.20 \\
\hline Vochysia gardineri Warm. & 82.60 & 0.11 & 17.29 \\
\hline Xylopia aromática (Lam.) Mart. & 82.88 & 0.27 & 16.84 \\
\hline
\end{tabular}

$\mathrm{VM}=$ volatile matter; $\mathrm{ASH}=$ ashes $; \mathrm{FC}=$ fixed carbon

Among the 34 species analyzed, Pouteria ramiflora $\left(15,006 \mathrm{Mcal} \mathrm{m}^{-3}\right)$, Miconia cuspidata $\left(16,177\right.$ Mcal $\left.\mathrm{m}^{-3}\right)$, and Emmotum nitens $\left(15,977\right.$ Mcal $\left.\mathrm{m}^{-3}\right)$ showed the highest energy density values. On the other hand, the species with the lowest energy density were Vochysia gardineri $\left(6,871\right.$ Mcal $\left.\mathrm{m}^{-3}\right), \quad$ Connarus perrottetti $\left(8,380\right.$ Mcal $\left.\mathrm{m}^{-3}\right)$, and Byrsonima laxiflora $\left(9,315 \mathrm{Mcal} \mathrm{m}^{-3}\right)$. The average value of energy density for the 34 species was $12,459 \mathrm{Mcal} \mathrm{m}^{-3}$.

According to Vidaurre et al. (2012) and Cunha (1989), the density has no direct relation with the amount of energy contained in the wood. Both studies, as well as the result observed in ours, mentioned no correlation between basic density and higher calorific value. However, these authors emphasize that the higher the density is, the greater the amount of energy contained per unit volume, 
which stimulates the interest in denser woods for burning. When the relationship between the variables of the immediate analysis (VM, ASH, and FC) and $\mathrm{HCV}$ was tested, a correlation was observed between $\mathrm{VM}$ and $\mathrm{FC}\left(\mathrm{R}^{2}=0.9927\right)$ (Figure 1$)$. The higher calorific value and basic density of the studied species did not present a significant relationship since the high-density species showed a low HCV (Figure 2). Table 2 and Figure 3 show the relationship between energy density and other variables.
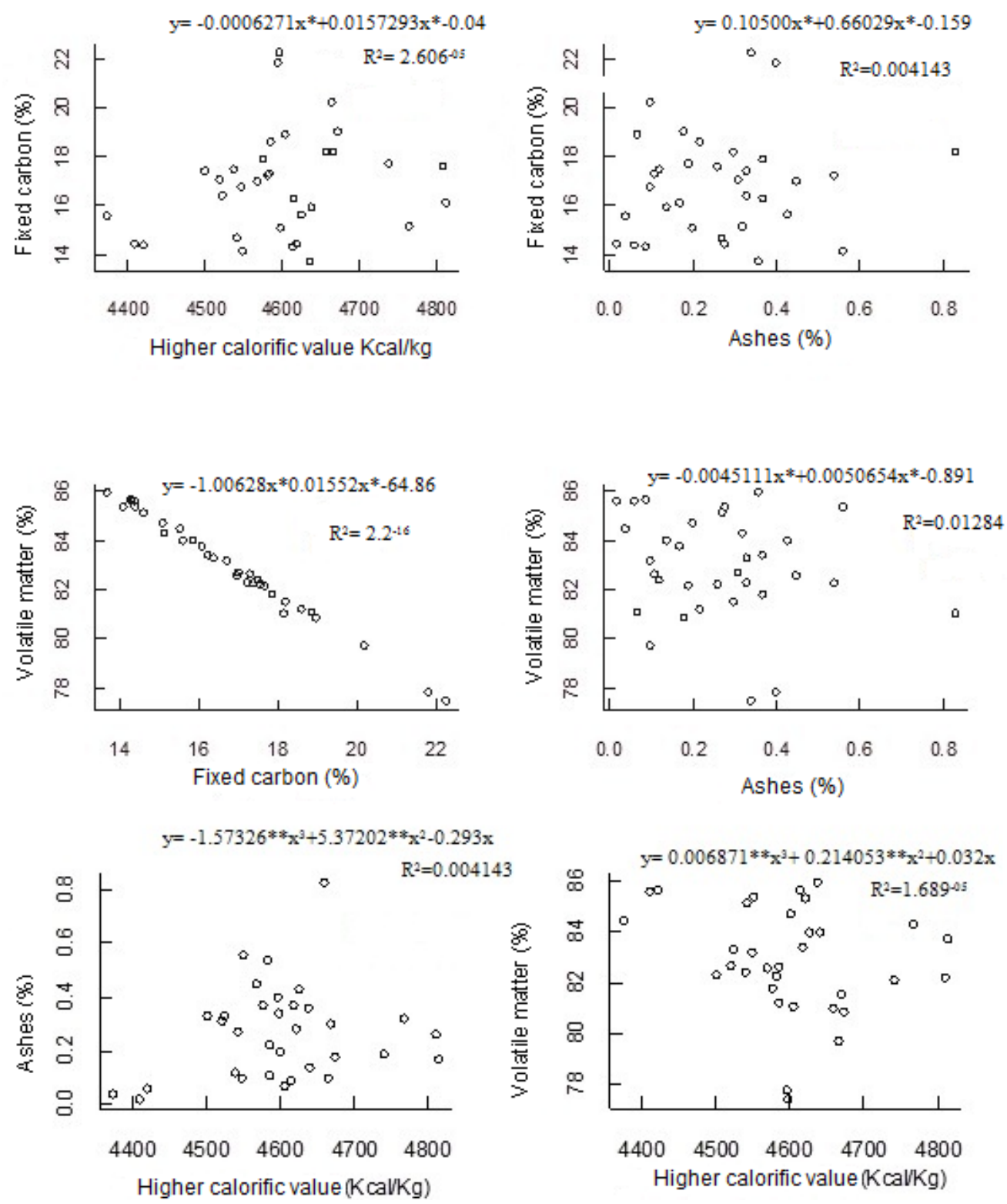

Figure 1. Relationship between fixed carbon, ashes, and volatile matter and higher calorific value of Cerrado tree species from Tocantins State, Brazil.

Table 2. Relationship between basic density $\left(\rho_{\mathrm{b}}\right)$, higher calorific value (HCV), ashes (ASH), and volatile matter (VM) of Cerrado tree species from Tocantins State, Brazil.

\begin{tabular}{llcll}
\hline Relation & $\mathbf{R}^{2}$ & $\mathbf{F}$ & $\mathbf{p}$ & Residual \\
\hline $\mathrm{Db} \times \mathrm{HCV}$ & $6.03^{-05}$ & 0.004705 & 0.94549 & 0.013738 \\
$\mathrm{DE} \times \mathrm{VM}$ & 0.001653 & 0.129144 & 0.720292 & $2.92^{11}$ \\
$\mathrm{DE} \times \mathrm{FC}$ & 0.006186 & 0.485523 & 0.488003 & $2.9 \mathrm{E}^{11}$ \\
$\mathrm{DE} \times \mathrm{ASH}$ & 0.036694642 & 0.08872 & 0.08872 & $2.81^{11}$ \\
$\mathrm{DE} \times \mathrm{Db}$ & 0.985211 & 5129.459 & 0.735273 & $3.35^{11}$ \\
\hline
\end{tabular}




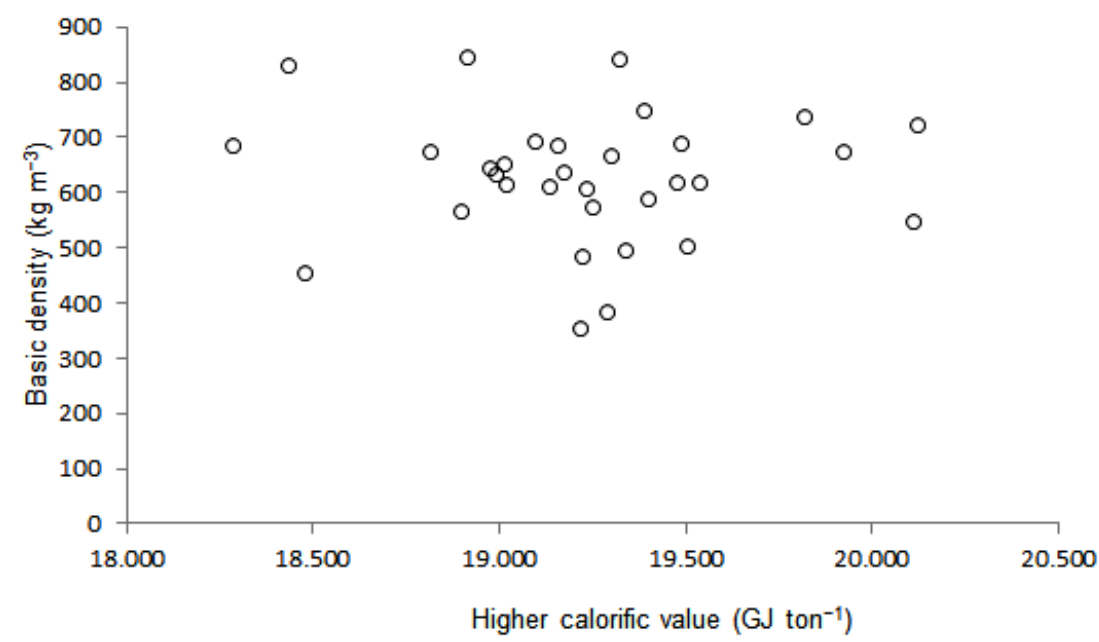

Figure 2. Relationship between higher calorific value and basic density of 34 Cerrado tree species from Tocantins State, Brazil.

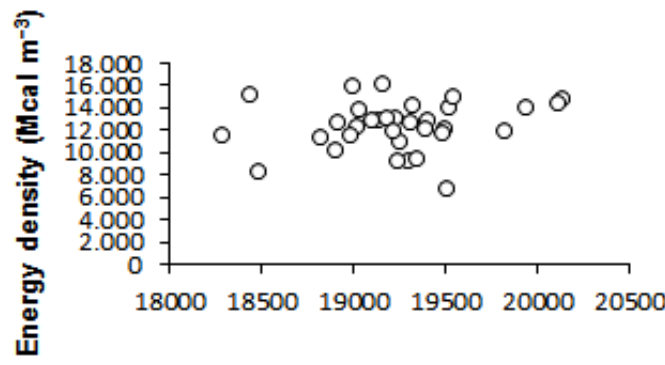

Higher calorific value (GJ ton ${ }^{-1}$ )

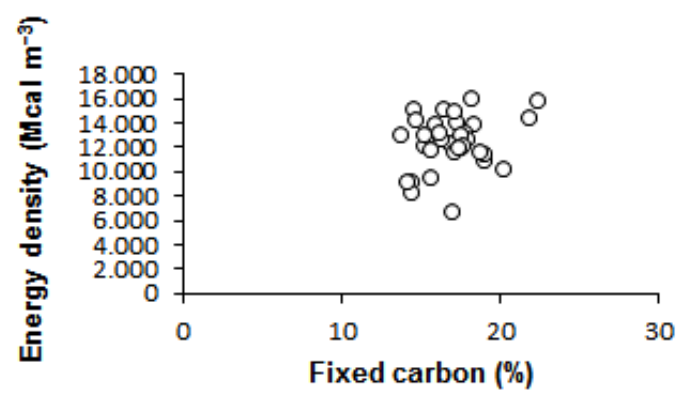

Figure 3. Relationship between energy density and calorific value, volatile material content (VM), fixed carbon content (FC), ash content (ASH) of 34 Cerrado tree species from Tocantins State, Brazil.

In a study on the energy potential of six-yearold eucalyptus trees, Lima et al. (2007) found 9,168 Mcal $\mathrm{m}^{-3}$ of energy density. Pinheiro, Rendeiro and Pinho (2005) studied the energy density of plant residues (fruit peels) and found values of energy density from 400 to 2,600 Mcal $\mathrm{m}^{-3}$. When analyzing six-year-old eucalyptus trees, Lima (2011) observed a value of energy density of 11,103 Mcal $\mathrm{m}^{-3}$ whereas Brito, Barrichelo and Seixas (1983), found values ranging from 7,843 to $12,038 \mathrm{Mcal} \mathrm{m}^{-3}$ for eucalyptus species. According to Lima (2011), energy density considers the energy contained in a given wood volume. The variation of values in our study was close to the values found in the literature,
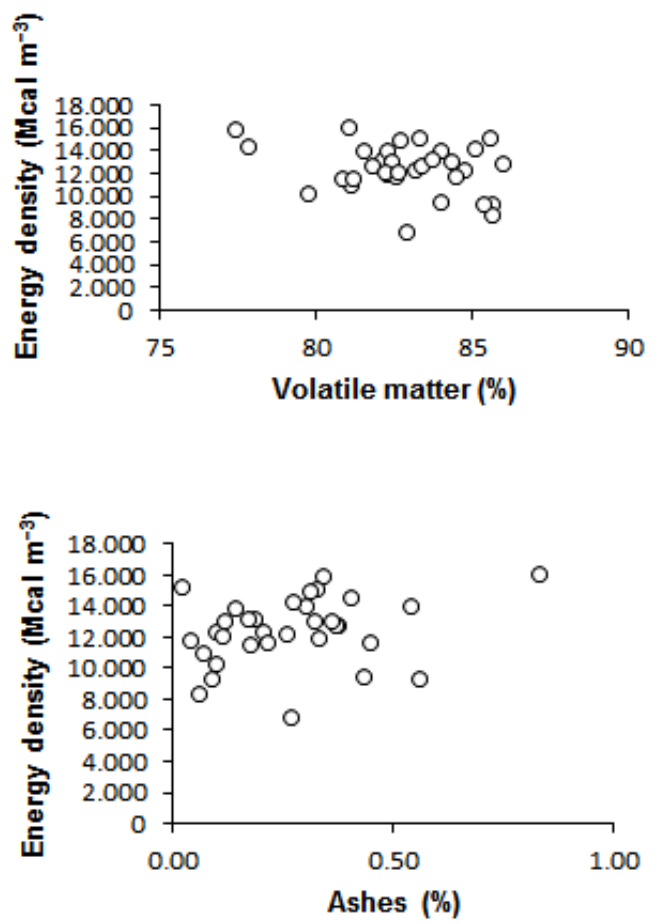

ranging from 6,871 to $16,177 \mathrm{Mcal} \mathrm{m}^{-3}$, with an average of $12,459 \mathrm{Mcal} \mathrm{m}^{-3}$. Although the average energy density in the literature does not present so much variation, few studies with native species can be found.

Brito and Barrichelo (1977) concluded that in the choice of wood to obtain charcoal with better chemical properties (higher contents of fixed carbon and lower of volatile substances and ashes), those with high lignin contents and high basic density should be sought. This provides an increase in the amount of dry matter in the oven. In a study with 108 forest species, Quirino et al. (2005) observed that the highest calorific value does not match the 
species with the highest basic density. In addition, Quirino et al. (2012) reported that low-density woods could be used for energy if converted into briquettes.

Fixed carbon is directly related to the calorific value, especially the charcoal, being the variation higher, ranging from $6 \%$ in a dry base of wood to up to $90 \%$ in charcoal. This may be the reason for the low relationship between the higher calorific value and fixed carbon content found in our study. Another possible explanation may be the presence of extractives. Vale, Sarmento and Almeida (2005) reported that the best use of wood for energy production as heat is linked to a higher specific mass, higher fixed carbon content, and lower volatile matter content. Souza (2010) observed that the parameter density might influence the calorific value of a material as the heat generated by combustion is related to the volume. Thus, wood and denser wood products presented higher calorific value per unit volume.

The coefficient of determination $\left(\mathrm{R}^{2}\right)$ presented in Table 3 showed that $98 \%$ of the energy density variation registered can be explained by the average basic density of the tree, with mean percentage errors of less than $2.1 \%$, as the standard error of the estimate $\left(\mathrm{S}_{\mathrm{yx}}\right)$. The model adjusted for energy density estimation as a function of the basic density is shown in Table 3. The residual distribution did not exceed a variation of $6 \%$ either to underestimate or overestimate the energy density of the tree by the basic density of the 34 species (Figure 4).

Table 3. Model adjustment to estimate the energy density of the tree (DE) as a function of its basic density.

\begin{tabular}{ccccc}
\hline $\begin{array}{c}\text { Model } \\
\mathrm{DE}=\beta 0+\beta 1 \times \mathrm{D}_{\mathrm{BA}}\end{array}$ & $\mathbf{R}^{2}$ adj. & $\mathbf{S}_{\mathbf{y x}}$ & $\mathbf{S}_{\mathbf{y x}} \mathbf{( \% )}$ & $\mathbf{F}$ \\
\hline $\mathrm{DE}=-1.25645+19.21955 \times \mathrm{D}_{\mathrm{BA}}$ & 0.98 & 277.06 & 2.15 & 4034.15 \\
\hline
\end{tabular}

$\mathrm{DE}=$ average energy density of the tree; $\beta 0+\beta 1=$ estimated coefficients; $\mathrm{D}_{\mathrm{BA}}=$ average basic density of the tree; $\mathrm{R}^{2}$ adj. $=$ coefficient of determination; Syx $=$ standard error of estimation; $F=F$ value from the analysis of variance.

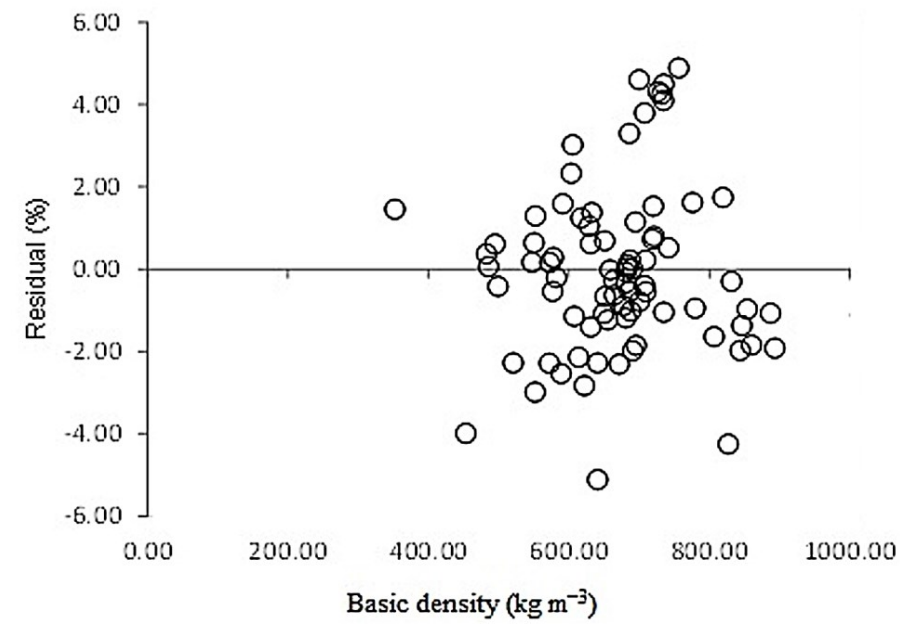

Figure 4. Residual distribution according to the adjusted model to determine the energy density as a function of the basic density of the tree.

The estimated energy density of the area was 1,378,541 Mcal $\mathrm{ha}^{-1}$. The proposed model for calculating the energy density as a function of the basic density facilitates the energy surveys in areas to be explored since only the values of basic density need to be obtained, without the need of calorific value analysis. The knowledge of the energy potential of the analyzed native species allows advancing in the studies for possible improvements in the quality of wood species directed to a sustainable forest energy production.

\section{CONCLUSION}

From the adjusted model, it is possible to calculate the energy density of species as a function of the basic density.

\section{REFERENCES}

ALMEIDA, C. C. F. et al. Qualidade energética da madeira e de briquetes produzidos a partir de Cupressus lusitanica Mill. Scientia Forestalis, 
Piracicaba, v. 43, n. 108, p. 1003-1011, 2015.

ANDRADE, A. M.; CARVALHO, L. M. Potencialidades energéticas de oito espécies florestais do Estado do Rio de Janeiro. Floresta e Ambiente, Seropédica, v. 5, n. 1, p. 24-42. 1998.

BARCELLOS, D. C. Caracterização do carvão vegetal através do uso de espectroscopia no infravermelho próximo. 2007, 129 p. Tese (Doutorado em Ciência Florestal: Área de Concentração em Tecnologia da Madeira) Universidade Federal de Viçosa, Viçosa, 2007.

BRITO, J. O. Expressão da produção florestal em unidades energéticas. In: CONGRESSO FLORESTAL PANAMERICANO, 1., CONGRESSO FLORESTAL BRASILEIRO, 7. Curitiba. Anais... Curitiba: SBS, SBEF, p. 280-282. 1993.

BRITO J. O. O uso energético da madeira. Estudos avançados, São Paulo, v. 21, n. 59, p. 185-193, 2007.

BRITO, J. O.; BARRICHELO, L. E. Correlações entre características físicas e químicas da madeira e a produção de carvão vegetal: i. Densidade e teor de lignina da madeira de eucalipto. IPEF, Piracicaba, v. 14, n. 14, p. 9-20. 1977.

BRITO, J. O.; BARRICHELO, L. E. G. Características do eucalipto como combustível: análise química imediata da madeira e da casca. IPEF, São Paulo, v. 16, n. 16, p. 63-70. 1978.

BRITO, J. O.; BARRICHELO, L. E. G. Aspectos técnicos da utilização da madeira e carvão vegetal como combustíveis. In: seminário de abastecimento energético industrial com recursos florestais, Anais... São Paulo, p. 101-137. 1982.

BRITO, J. O.; BARRICHELO, L. E. G.; SEIXAS, F. Análise da Produção Energética e de Carvão Vegetal de Espécies de Eucalipto. ESALQ, IPEF, São Paulo, v. 23, n. 23, p. $53-56.1983$.

CHAVES, A. M. B. et al. Características energéticas da madeira e carvão vegetal de clones de Eucalyptus spp. Enciclopédia biosfera, Goiânia, v. 9, n. 17, p. 533-542, 2013.

CINTRA, T. C. Avaliação energética de espécies florestais nativas plantadas na região do médio Paranapanema, SP. 2009, 84 p. Dissertação (Mestrado em recursos Florestais: Área de Concentração em Tecnologia de Produtos Florestais) - Universidade de São Paulo Escola Superior de Agricultura Luiz de Queiroz, Piracicaba, 2009.
COLEN, A. G. N.; SILVA, D. S.; MARTINS, A. K. E. Elaboração de mapas de Geounidades do Parque Estadual de Lajeado no município de Palmas - TO. In: XIII Simpósio Brasileiro de Sensoriamento Remoto. Palmas. Anais... Palmas: INPE, p. 24552462. 2007.

COUTO, L. C. C. et al. Vias de valorização energética. Biomassa \& Energia, Viçosa, v. 1, n. 1, p. 71-92. 2004 .

CUNHA, M. P. S. C. Estudo químico de 55 espécies lenhosas para geração de energia em caldeiras. In: ENCONTRO BRASILEIRO EM MADEIRAS E EM ESTRUTURAS DE MADEIRA, 3. São Carlos. Anais... São Carlos, v. 2. p. 93-121. 1989.

DRAPER, N. R.; SMITH, H. Applied regression analysis. New York: J. Wiley, 1981. 709 p.

LIMA E. A. Caracterização dendroenergética de árvores de Eucalyptus benthamii. Pesquisa Florestal Brasileira, Colombo, v. 31, n. 65, p. 9-17. 2011.

LIMA, E. A. et al. Caracterização individual de árvores de $E$. benthamii para uso energético. Colombo: Embrapa Florestas, 2007. 25 p. (Embrapa Florestas, Boletim de Pesquisa e Desenvolvimento, n. 35).

MIGUEL, E. P. et al. Floristic-structural characterization and successional group of tree species in the Cerrado biome of Tocantins state, Brazil. Revista Caatinga, Mossoró, v. 29, n. 2, p. 393-404, 2016.

MORAIS, S. A. L.; NASCIMENTO, E. A.; MELO, D. C. Análise da madeira de Pinus oocarpa PARTE I - Estudo dos constituintes macromoleculares e extrativos voláteis. Revista Árvore, Viçosa, v. 29, n. 3, p. 461-470. 2005.

MOUTINHO, V. H. P. et al. Propriedades Químicas e Energéticas de Madeiras Amazônicas do Segundo Ciclo de Corte. Floresta e Ambiente, Seropédica, v. 23, n. 3, p. 443-449, 2016.

NASCIMENTO, M. D.; BIAGGIONI, M. A. M. Avaliação energética do uso de lenha e cavaco de madeira para produção de energia em agroindústria. Revista Energia na Agricultura, Seropédica, v. 25, n. 3 , p. $104-117.2010$.

PINCELLI, A. L. P. S. M. Características dos resíduos da colheita de madeira de eucalipto e pinus, submetidos, ao tratamento térmico, com foco na aplicação energética. 2011. 126 p. Tese (Doutorado em Recursos Florestais: Área de Concentração em Tecnologia da Madeira) Universidade de São Paulo Escola Superior de 
Agricultura Luiz de Queiroz, Piracicaba, 2011.

PINHEIRO, G. F.; RENDEIRO, G.; PINHO, J. T. Densidade energética de resíduos vegetais. Biomassa e Energia, Viçosa, v. 2, n. 2, p. 113- 123. 2005.

QUIRINO, W. F. et al. Poder calorífico da madeira e de matérias lignocelulosicos. Revista da madeira, Bento Gonçalves, v. 89, n. 89, p. 100-106. 2005.

QUIRINO, W. F. et al. Densitometria de raio X na análise da qualidade de briquetes de resíduos de madeira. Scientia Forestalis, Piracicaba, v. 40, n. 96, p. 525-536, 2012.

R DEVELOPMENT CORE TEAM. R: A language and environment for statistical computing. $R$ Foundation for Statistical Computing, Vienna, Austria. ISBN 3-900051-07-0. Disponível em: $<$ http://www.R-project.org/,2011>. Acesso em: 20 mai. 2015.

SILVA, A. G. Condicionamento de resíduos de Eucalyptus grandis para produção de biocombustível sólido. 2013. 130 p. Tese (Doutorado em Química: Área de Concentração em Química da Madeira) - Universidade Federal da Bahia - UFBA, Salvador, 2013.

SIlVA, C. J.; VAlE, A. T.; MIGUEL, E. P. Densidade básica da madeira de espécies arbóreas de Cerradão no estado de Tocantins. Pesquisa Florestal Brasileira, Colombo, v. 35, n. 82, p. 63-75, 2015.

SOUZA, M. M. Caracterização e viabilidade econômica do uso energético de resíduos da colheita florestal e do processamento de Pinus taeda L. 2010, 76 p. Dissertação (Mestrado em Ciência Florestal: Área de Concentração em tecnologia da Madeira) - Universidade Federal do Paraná, Curitiba, 2010.

VALE, A. T.; BRASIL, M. A. M.; LEÃO, A. L. Quantificação e caracterização energética da madeira e casca de espécies do cerrado. Ciência Florestal, Santa Maria, v. 12, n. 1, p. 71-80, 2002.

VALE, A. T.; SARMENTO, T. R.; ALMEIDA, A. N. Caracterização e Uso de Madeiras de Galhos de Árvores Provenientes da Arborização de Brasilia DF. Ciência Florestal, Santa Maria, v. 15, n. 4, p. 411-420, 2005.

VENTURA FILHO, A. O Brasil no contexto energético mundial. 1. ed. São Paulo, SP: NAIPPE/ USP, 2009. $22 \mathrm{p}$.

VIDAURRE, G. B. et al. Propriedades energéticas da madeira e do carvão de paricá (Schizolobium amazonicum). Revista Árvore, Viçosa, v. 36, n. 2, p. $365-371.2012$. 